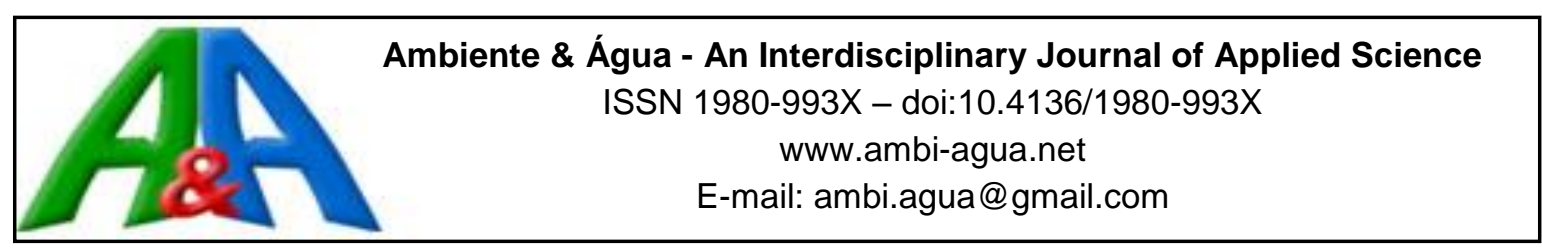

\title{
Climatic zoning for eucalyptus cultivation through strategic decision analysis
}

ARTICLES doi:10.4136/ambi-agua.2119

Received: 30 Mar. 2017; Accepted: 18 Dec. 2017

\author{
Micael de Souza Fraga ${ }^{1 *}$; Eduardo Morgan Uliana²; Demetrius David da Silva ${ }^{\mathbf{1}}$; \\ Flávio Bastos Campos ${ }^{1}$; Maria Lúcia Calijuri ${ }^{1}$; Diego Magalhães de Souza Santos ${ }^{1}$ \\ ${ }^{1}$ Universidade Federal de Viçosa (UFV), Viçosa, MG, Brasil \\ E-mail: micaelfraga@gmail.com,demetrius@ufv.br, flaviobastoscampos@gmail.com, calijuri@ufv.br, \\ diegomagsouza@gmail.com \\ ${ }^{2}$ Universidade Federal do Mato Grosso (UFMT), Sinop, MT, Brasil \\ Instituto de Ciências Agrárias e Ambientais (ICAA). E-mail: morganuliana@gmail.com \\ *Corresponding author
}

\begin{abstract}
The rapid expansion of eucalyptus cultivation necessitates studies that can identify areas amenable to the planting and development of its different varieties. This study therefore aimed to verify the suitability of two varieties of eucalyptus in the state of Espírito Santo, using Geographic Information Systems supported by strategic decision analysis. Mean precipitation, mean temperature, hydric deficit and land slope data were used as decision factors. These factors were submitted to fuzzy standardization, aggregated and compensated by the Weighted Linear Combination (WLC) process, resulting in the final aptitude mapping. For the reconciliation of conflict areas between the varieties, the Multi-objective Land Allocation (MOLA) module was used to maximize the suitability of the land for the objective. The WLC analysis allowed us to identify the suitability of the areas and with the use of the MOLA module it was possible to resolve the conflict of suitability between the two eucalyptus varieties. Most of the state of Espírito Santo is highly suitable for the the development of varieties. The northwestern region and part of the northern region presented less suitability for both analyzed eucalyptus varieties. Considering the $10,000 \mathrm{~km}^{2}$ most adaptable area for eucalyptus cultivation in the state of Espírito Santo, it was verified that the most suitable areas for planting the two eucalyptus varieties are located in the mountainous regions, part of the southern region and near the northeastern coast.
\end{abstract}

Keywords: agricultural aptitude, Espírito Santo state, fuzzy logic.

\section{Zoneamento climático para cultivo de eucalipto por meio de análise estratégica de decisão}

\section{RESUMO}

A rápida expansão do eucalipto leva à necessidade de estudos que identifiquem áreas com aptidões climáticas para a implantação e desenvolvimento dos seus diferentes tipos de espécies. Assim sendo, este trabalho teve como objetivo verificar a aptidão de áreas para a implantação de duas espécies de eucalipto no estado do Espírito Santo, utilizando Sistemas de Informações Geográficas apoiado em análise estratégica de decisão. Na análise foram utilizados como 
fatores de decisão dados de precipitação média, temperatura média, déficit hídrico e declividade do estado do Espírito Santo. Estes fatores foram submetidos à padronização fuzzy, agregados e compensados pelo processo de Combinação Linear Ponderada (WLC), resultando no mapeamento final de aptidão. Para a conciliação das áreas de conflito entre as espécies utilizouse o módulo para Alocação Multi-objetiva do Terreno (MOLA), maximizando assim a adequabilidade do terreno para o objetivo. A análise WLC permitiu identificar a adequabilidade das áreas e com o uso do módulo MOLA foi possível resolver o conflito de adequabilidade entre as duas espécies de eucalipto. A maior parte do estado do Espírito Santo apresenta alta adequabilidade para o desenvolvimento das espécies, sendo a região noroeste e parte da região norte as que apresentaram menor adequabilidade para ambas as espécies de eucalipto analisadas. Considerando os $10.000 \mathrm{~km}^{2}$ mais adaptáveis ao cultivo do Eucalipto no estado do Espírito Santo verificou-se que as áreas mais adequadas para plantio das duas espécies de eucalipto estão localizadas nas regiões serrana, parte da sul e próximas ao litoral nordeste.

Palavras-chave: Espírito Santo, lógica fuzzy, zoneamento.

\section{INTRODUCTION}

The productive potential of eucalyptus cultivated in tropical regions is very high and has few restrictions. Eucalyptus plantations totaled 5.56 million ha of land in Brazil in 2014 (IBÁ, 2015), and about 8 million hectares are projected for 2020 (Sartori, 2008). One major advantage of eucalyptus forests is their rapid growth rate, which is well known for being the highest in the world among hardwood forests (Myburg et al., 2014). According to Scolforo et al. (2017), the states of Bahia and Espírito Santo have $15.5 \%$ of the eucalyptus plantations in Brazil and they are located in the subtropical zone.

Brazil's high competitiveness in the forestry sector is based on favorable environmental conditions and on the efficiency of the employed technology as a result of solid investments in research and development by the companies, along with universities and other research institutions (Ribeiro et al., 2009). Eucalyptus wood can be used for cellulose, siderurgy, charcoal, firewood, plywood and wood sheets. It has a great influence on the national economy. Characteristics such as favorable natural conditions, advanced technological forestry development and other privileged conditions (geographic location, infrastructure, transportation logistics and industrial plants diversification) favor the growth of foprestry in Espírito Santo state (Valverde et al., 2005). However, the fast expansion of eucalyptus cultivated area with its high number of varieties and its great adaptability to the most varied ecological conditions led to the need for studies that could predict its productive capacity in different environments (Bognola et al., 2009).

According to Xavier et al. (2013), eucalyptus crops are often established in locations with high atmospheric demand and sparse, irregular rates of annual rainfall, which endanger both the success and productivity of the crops. Therefore, the climatic zoning is an important tool for the delimitation of areas with climatic aptitudes for the planting and development of forest varieties, as established through climatic and hydrological indicators of the region. It also helps us in the decision-making process that can bring direct benefits to the crop (Klippel et al., 2013).

The use of Geographic Information Systems (GIS) to identify areas where economically important forest cultivation may occur is of great value, because it provides the zoning elaboration that aggregates several types of information into a single database, making it possible to differentiate areas with greater or lesser adaptability (Facco et al., 2012; Francelino et al., 2012; Moraes et al., 2014; Menezes et al., 2015). Due to the growing importance of eucalyptus cultivation, the objective of this work was to determine areas climatically suitable for Eucalyptus grandis and Eucalyptus urophyla development in Espírito Santo state using GIS and strategic decision analysis. 


\section{MATERIAL AND METHODS}

\subsection{Studied area and database}

The area of this study was the state of Espírito Santo, with a $46,078 \mathrm{~km}^{2}$ total area, located in the southwestern region of Brazil. Geographically, the state lies between the meridians $39^{\circ} 38^{\prime}$ and $41^{\circ} 50^{\prime}$ west longitude and between the parallels $17^{\circ} 52^{\prime}$ and $21^{\circ} 19^{\prime}$ south latitude. According to the Köppen classification system, the region fits into climatic zones $\mathrm{A}$ and $\mathrm{C}$, which identify humid climates. The $\mathrm{Aw}, \mathrm{Am}, \mathrm{Cf}$ and $\mathrm{Cw}$ climatic subtypes are also found in the state, as well as the Cfa, Cfb, Cwa and Cwb variations (Siqueira et al., 2004).

In order to identify suitable areas for eucalyptus planting, air temperature, precipitation, hydric deficit and land slope data were used. The data of air temperature, precipitation and hydric deficit were chosen because they are the main parameters representing the thermal and water conditions for the planting of eucalyptus (Ribeiro et al., 2009), which are also used in several other climatic zoning studies (Almeida et al., 2013; Barbieri et al., 2015; Pádua et al., 2014; Pezzopane et al., 2010; Santos et al., 2016).

The mean annual rainfall was obtained using the historical series of 79 rainfall stations belonging to the hydrometeorological network of the National Water Agency (ANA), to the National Meteorological Institute (INMET) and to the Center for Weather Forecasting and Climate Studies (CPTEC), considering a historical series of 30 years of data (1979-2008). The pluviometric stations location is shown in Figure 1.

In ANA pluviometric stations, no air temperature measurements were performed. Those were obtained using the CALCLI software developed by Stock et al. (1991). The software makes temperature estimates based on geographic coordinates and distance from the coast. For this purpose, the geographic coordinates of the 79 rainfall stations were used.

Based on the meteorological data for average air temperature and rainfall for all locations, the monthly climatic hydric balance was calculated using the methodology proposed by Thornthwaite and Mather (1955, described by Pereira et al., 2002). This method was chosen because of the compatibility with the available climatic data and reliability of the results. In this research, a value equivalent to $300 \mathrm{~mm}$ was considered for soil water storage capacity (DAC), based on the recommendations of Pereira et al. (2002).

The land slope was determined by means of a digital elevation model, obtained by SRTM (Shuttle Radar Topography Mission) radar data, with a spatial resolution of 90 meters, equivalent to a scale of 1:250,000 (Miranda, 2005).

The interpolation of temperature, precipitation and hydric deficit data was performed by means of ordinary kriging. Thus, for spatial dependence analysis, the semivariance was obtained as a function of the distance separating the samples. Works such as Carvalho and Assad (2005); Castro et al. (2010); and Gomes et al. (2011) obtained satisfactory results when using ordinary kriging to study the spatial distribution of rainfall and hydric deficit.

The experimental semivariogram was obtained from the calculation of the semivariance as a function of different distances. It was then necessary to adjust a theoretical model to this experimental semivariogram. The theoretical models of semivariogram (Soares, 2006) were spherical, exponential, Gaussian and linear. Using the nugget effect, and the plateau and range obtained by means of the theoretical semivariogram, it was possible to obtain the spatial distribution of the variable under study by means of ordinary kriging. The theoretical model of semivariogram chosen provided the highest correlation between the values observed and estimated by kriging in the cross-validation, evaluated by the Pearson correlation coefficient tested by the $\mathrm{t}$ test at the $5 \%$ probability level. 


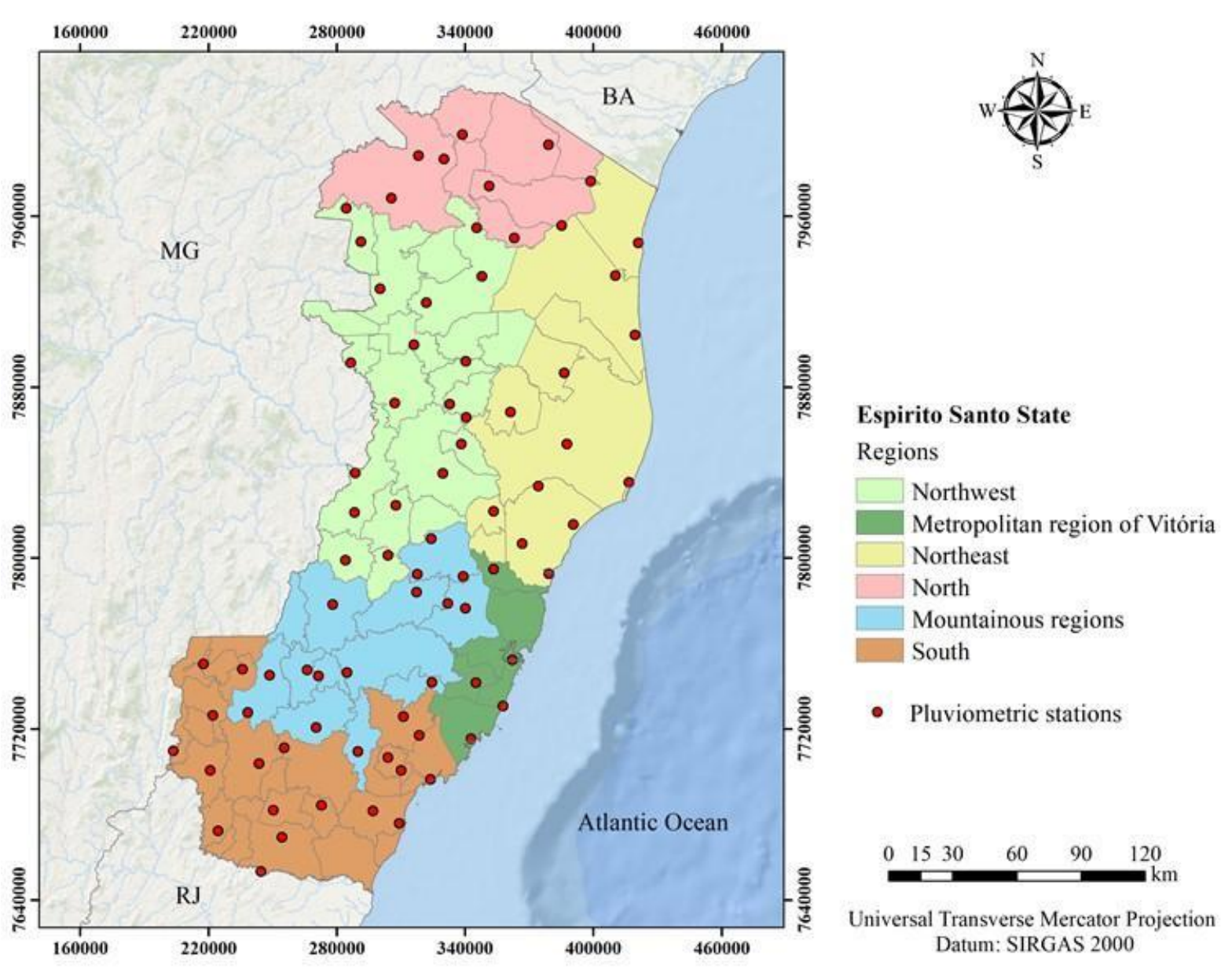

Figure 1. Map with the pluviometric stations location used in the study.

In order to obtain the restrictions related to the study, geographic information related to the location of flooded areas, special areas (environmental protection area, biological reserves, state parks, among others), hydrography and urban boundary were used.

\subsection{Evaluation by multiple criteria}

The zoning consisted mainly of the identification of areas climatically suitable for the cultivation of Eucalyptus grandis and Eucalyptus urophylla, in which the ideal hydrothermal conditions were established for their development and consequent productivity. In this work, the fuzzy concept was used to give all Espírito Santo's locations a representative value of their suitability degree for a certain factor.

Due to the fact that several factors were used to determine suitable areas, and considering that they have different weights in the decision process, a weighting of the variables was established using the Idrisi Selva software WEIGHT matrix according to each factor's degree, described by Pinto (2010). The final importance of each variable was estimated through the AHP (Analytical Hierarchy Process) Method, applying the comparison matrix per pair. According to Calijuri et al. (2002), the algorithm used assists the establishment's final importance by comparing the relative importance of the variables, decreasing subjectivity in the decision.

The importance of the respective criteria was assigned according to their importance to the proposal. The weights of the factors used in the analysis were: 0.522 for annual hydric deficit; 0.1998 for average annual temperature; 0.1998 for annual mean rainfall; and 0.0781 for land slope, totaling 1 . The hydric deficit got the greatest weight because it was considered, among 
the evaluated parameters, the main cause of losses in forest productivity (Gonçalves and Passos, 2000; Teixeira et al., 2013). The slope received the lowest value because it was not a climatic parameter; however it was considered due to its effect on the productivity of wood-harvesting machines (Leite et al., 2014; Malinovski et al., 2006).

The requirements of the eucalyptus varieties analyzed in this study regarding the temperature; precipitation; and hydric deficit; and land slope factors can be seen in Table 1.

Table 1. Established requirements for the planting of two eucalyptus varieties.

\begin{tabular}{lcccc}
\hline Varieties & $\begin{array}{c}\text { Average Annual } \\
\text { Temperature }\left({ }^{\circ} \mathrm{C}\right)\end{array}$ & $\begin{array}{c}\text { Average Annual } \\
\text { Rainfall }(\mathrm{mm})\end{array}$ & $\begin{array}{c}\text { Annual Hydric } \\
\text { Deficit (mm) }\end{array}$ & Land slope (\%) \\
\hline Eucalyptus grandis & $6-32$ & $1000-1800$ & $0-400$ & $0-100$ \\
Eucalyptus urophyla & $12-29$ & $1000-1500$ & $0-400$ & $0-100$ \\
\hline
\end{tabular}

Source: Ribeiro et al. (2009).

Choosing the suitability function, the relationship between the criterion and the decision sets, along with information availability, were used to infer the fuzzy member. In most cases, sigmoidal or linear functions are enough. For the temperature and precipitation factors, the symmetrical sigmoidal function was used, as can be seen in Figure 2, where it is considered that suitability increases from point "a" to point "b", it maintains the maximum from "b" to "c" and decreases from "c" to "d". For the factors of hydric deficit and land slope, we used decreasing functions, where it is considered that the suitability goes to maximum the closer it is to point "a". Figure 2 shows the adequacy functions used in this study. Table 2 shows the limits used in the adequacy functions for each factor under analysis.
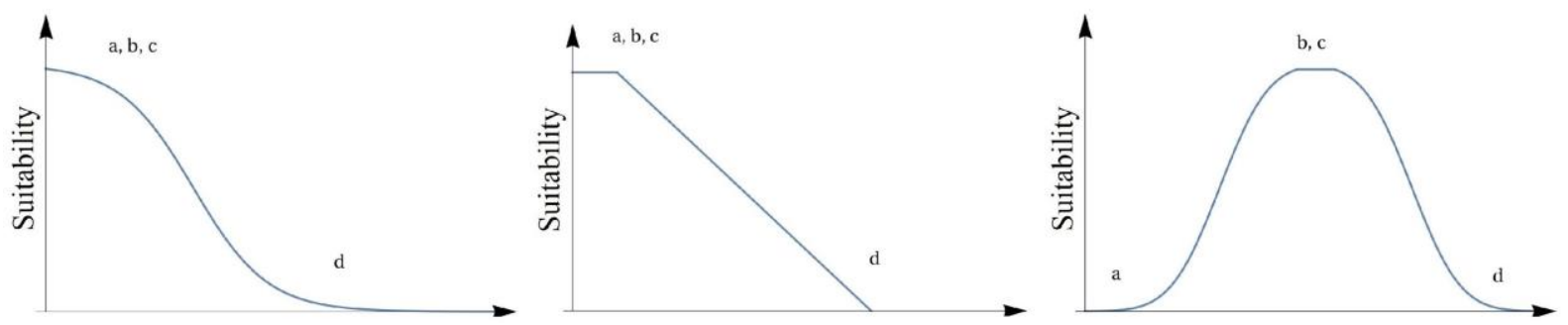

Figure 2. Sigmoidal decreasing (a), linear decreasing (b) and sigmoidal symmetric (c).

Table 2. Limit of adequacy functions for each analyzed factor.

\begin{tabular}{lccccc}
\hline Function & Factor & $\mathrm{a}$ & $\mathrm{b}$ & $\mathrm{c}$ & $\mathrm{d}$ \\
\hline \multirow{4}{*}{ Sigmoidal symmetric } & Temperature $^{1}$ & 0 & 6 & 32 & 32,5 \\
& Temperature $^{2}$ & 0 & 12 & 29 & 29,5 \\
& Precipitation $^{1}$ & 0 & 1000 & 1800 & 1900 \\
\multirow{3}{*}{ Sigmoidal decreasing } & Precipitation $^{2}$ & 0 & 1000 & 1500 & 1600 \\
\multirow{2}{*}{ Linear decreasing } & HD $^{1}$ & 0 & - & - & 400 \\
& HD $^{2}$ & 0 & - & - & 400 \\
& Land slope $^{1}$ & 0 & - & - & 100 \\
& Land slope $^{2}$ & 0 & - & - & 100 \\
\hline
\end{tabular}

1: Eucalyptus grandis; 2: Eucalyptus urophylla.

In order to finish the factor aggregation process, we used the Weighted Linear Combination (WLC) method of the Idrisi Selva software in the Multi Criteria Evaluation (MCE) module, which allows us to compensate the factors. In this process, the factors will be standardized on a continuous suitability scale from zero, the less adequate, to 255 , the most adequate. The WLC 
analysis was done by multiplying each standardized factor by its obtained weight and adding up the results below.

The areas can be considered suitable for both eucalyptus varieties ("conflict areas"), since both species of eucalyptus have common ranges for temperature and precipitation, and the same ranges for hydric deficit and slope. Thus, the Multi-Objective Land Allocation Module (MOLA) was used in this study to identify "conflicting" areas and to obtain a conciliatory solution considering the suitability for the two eucalyptus varieties' development.

The MOLA module identifies a conciliatory solution to maximize the land suitability for each objective, considering the weights assigned to each of them. For this analysis, it was decided to identify the most adaptable $10,000 \mathrm{~km}^{2}$ for eucalyptus cultivation, in order to identify potential areas for the expansion of these crops in the state of Espírito Santo. In MOLA, the same weights were assigned to the varieties, as well as to the division of the area, with $5,000 \mathrm{~km}^{2}$ for each variety, considering that they have the same weight of importance in the state.

\section{RESULTS AND DISCUSSION}

Figure 3 shows a spatial distribution of the values of temperature, precipitation, hydric deficit and slope of the terrain that were obtained in the present study and taken as a basis for the climatic zoning of the eucalyptus crop in the state of Espírito Santo.

The annual average temperature of the state of Espírito Santo is approximately $22.6^{\circ} \mathrm{C}$, and varies from $17^{\circ} \mathrm{C}$ to $24^{\circ} \mathrm{C}$, with a thermal amplitude of $7^{\circ} \mathrm{C}$. When comparing these values with the optimal temperature ranges for eucalyptus species, it is noted that both are entirely within the mean annual values for the state.

The mean annual precipitation found for the state of Espírito Santo was approximately $1256.67 \mathrm{~mm}$ year-1, varying from 916 to $1766 \mathrm{~mm}$ year-1. It is noted that the highest values of precipitation occur in the southern, metropolitan and mountainous regions of the state. The lowest rainfall is observed in the north, northwest and northeast regions. In this scenario, according to Ribeiro et al. (2009), there are restrictions regarding the rainfall for the cultivation of eucalyptus species, since both species have $1000 \mathrm{~mm}$ as a lower limit of total annual precipitation. On the other hand, the species Eucalyptus urophylla has an upper limit of suitability of $1500 \mathrm{~mm}$ year -1, which is lower than that shown in some regions of the state.

The annual hydric deficit varied from 0 to $349 \mathrm{~mm}$ year-1, with the lowest values in the southern, metropolitan and mountain regions, and highest values in the north and northwest regions of the state. However, all regions are at the limit of the favorable fitness class for both eucalyptus species (Ribeiro et al., 2009).

From the spatial distribution of the factors and using the WLC analysis, adequacy maps were obtained for planting Eucalyptus grandis and Eucalyptus urophylla varieties in Espírito Santo state (Figure 4). The integration process factor resulted in the identification of areas with high potential for eucalyptus crop implantation, varying from 0 to 255 .

It can be seen from Figure 4 that there are areas across the entire state suitable for the planting of forest stands of the studied varieties, according to the established bases for zoning. Generally, the identification of suitable areas for planting different varieties uses boolean logicbased modeling (Francelino et al., 2012; Rody et al., 2012; Sperandio et al., 2010), which is easy to apply, but in practice is considered very conservative in terms of risks, since the problem's solution is obtained satisfying all criteria. However, the WLC procedure avoided the rigid boolean decision on the definition of a location, and it has been widely used to characterize classes that do not have or do not set strict limits. According to Calijuri et al. (2002), by rescaling the factors on a standard continuous scale it is possible to compare them and combine them as in the boolean case. 


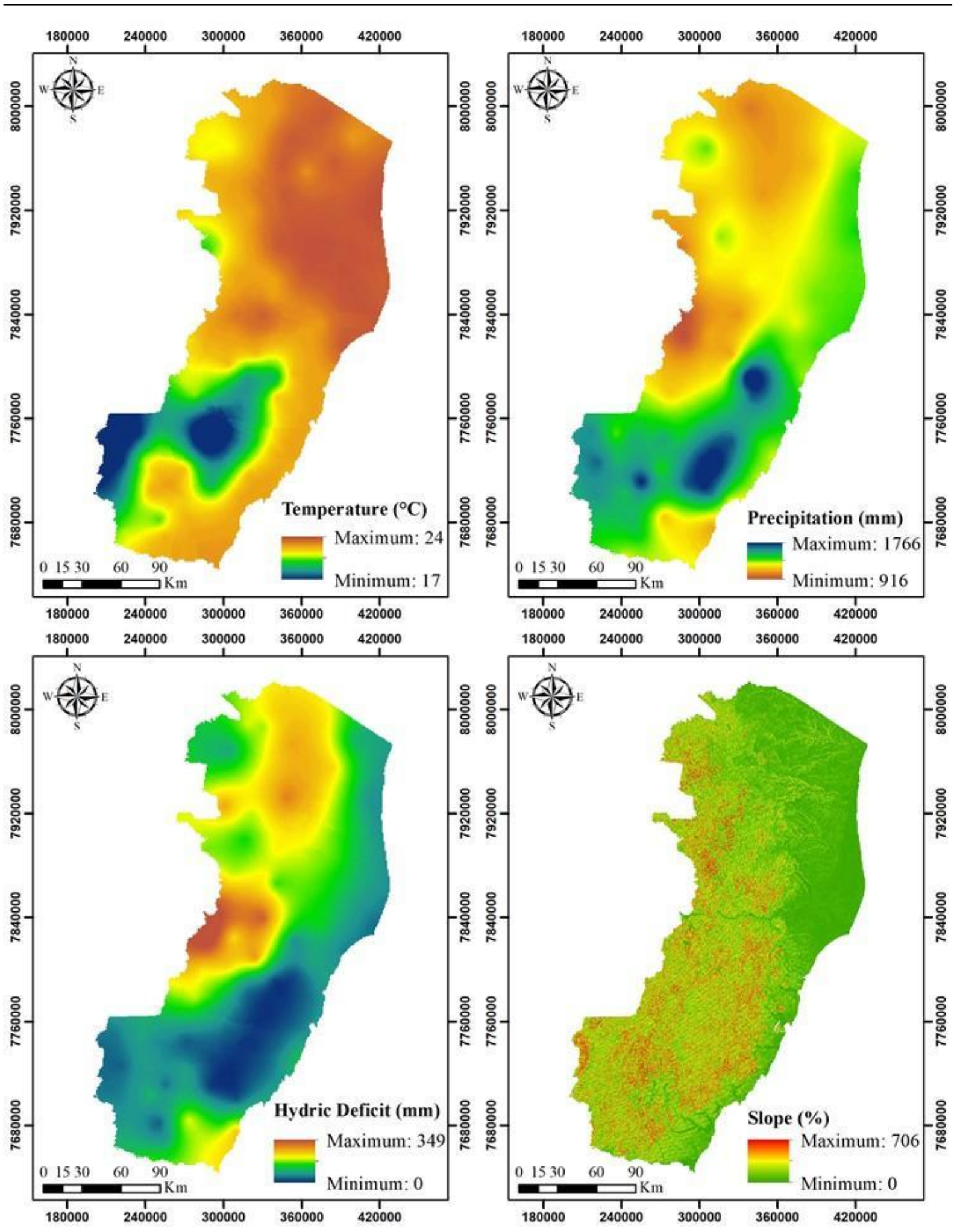

Figure 3. Precipitation, temperature, hydric deficit and slope maps used in the study. 


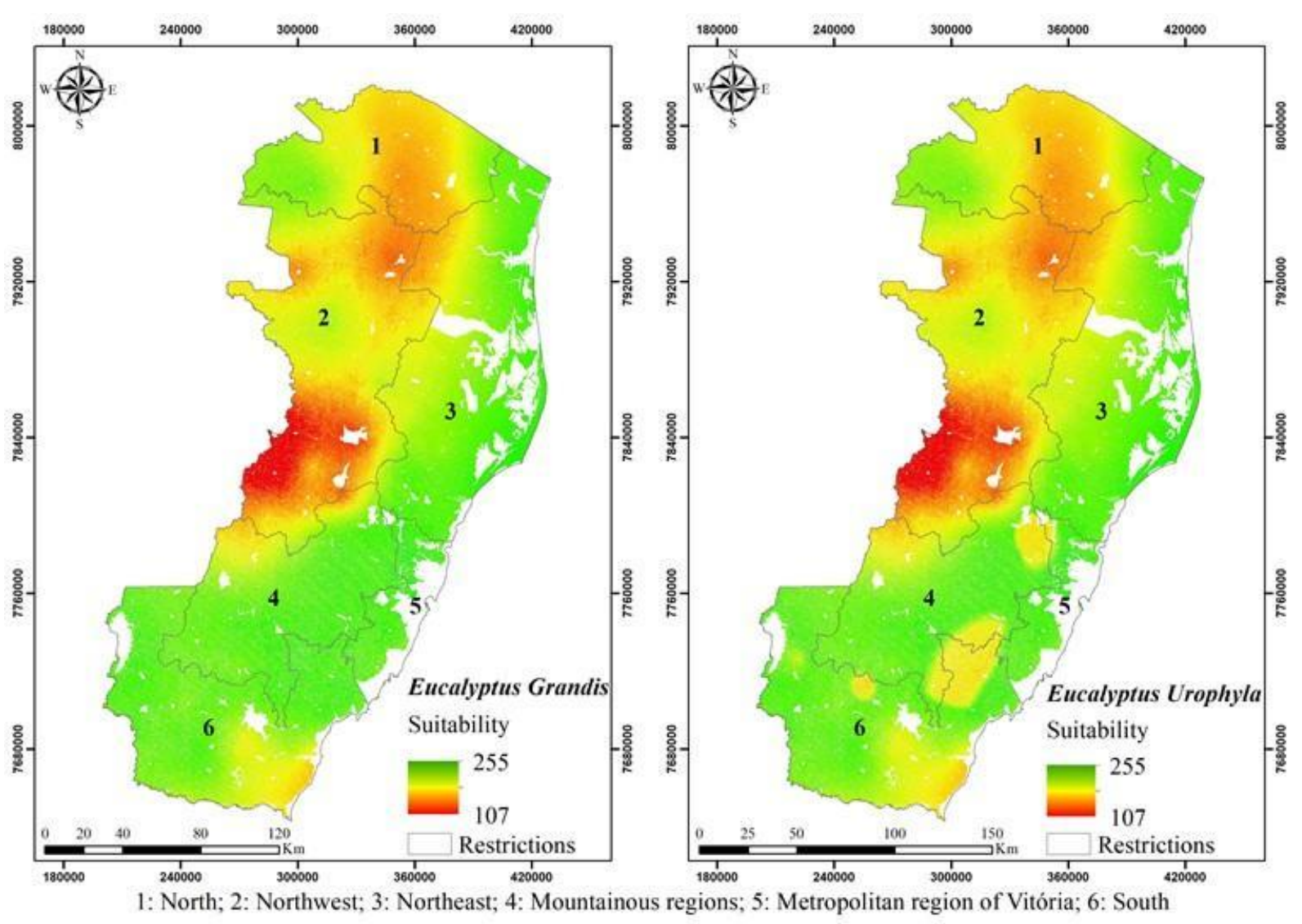

Figure 4. Suitability map for Eucalyptus grandis and for Eucalyptus urophylla.

The less suitable areas have characteristics that adversely interfere in crop growth, such as high land slope, high hydric deficit and large variations in the ranges of suitability for precipitation and temperature. However, most of Espírito Santo state has high suitability for the development of these varieties. The northwestern region and part of the northern region are the ones that showed less suitability for both analyzed varieties of eucalyptus. This behavior is related to the highest values of hydric deficit in these regions. Based on the WLC analysis, it is observed that, although the maximum value found is within the range recommended by Ribeiro et al. (2009), the sigmoidal decreasing function used for the hydric deficit makes this parameter a limiting factor for the cultivation of the species, since the suitability of the areas decreases as the value of the hydric deficit deviates from 0 (Figure 2).

Similar results were also found by Sperandio et al. (2010) for species of Eucalyptus grandis and Eucalyptus urophylla. Using hybrid species of Eucalyptus grandis $x$ Eucalyptus urophylla, Tatagiba et al. (2015) and Xavier et al. (2013) concluded that high values of hydric deficit reduced the production of dry wood at the end of the eucalyptus productive process.

In contrast to the variety Eucalyptus grandis, it is verified that the variety Eucalyptus urophylla presented a lower suitability in some localities of the mountain region. This behavior is due to the precipitation factor, which exceeded the upper limit of the optimum range for this variety development. In his work, Sperandio et al. (2010) also carried out a climatic zoning for the cultivation of different species of eucalyptus in the state of Espírito Santo. The authors concluded that the entire state is climatically suitable for the development of the studied eucalyptus species. Ribeiro et al. (2011) point out that productivity in areas where the climate is unfavorable is not uneconomical. However, if they are planted in areas other than those zoned as suitable, the species may not reach their productive potential. 
From the suitability images, it was also possible to obtain the most suitable areas of the whole state of Espírito Santo to plant the analyzed varieties, as well as the areas of conflict among them, the suitable areas to plant both varieties (Figure 5 (a)). On Figure 5 (b) the results can be seen after the varieties' conflict resolution, by the MOLA tool.
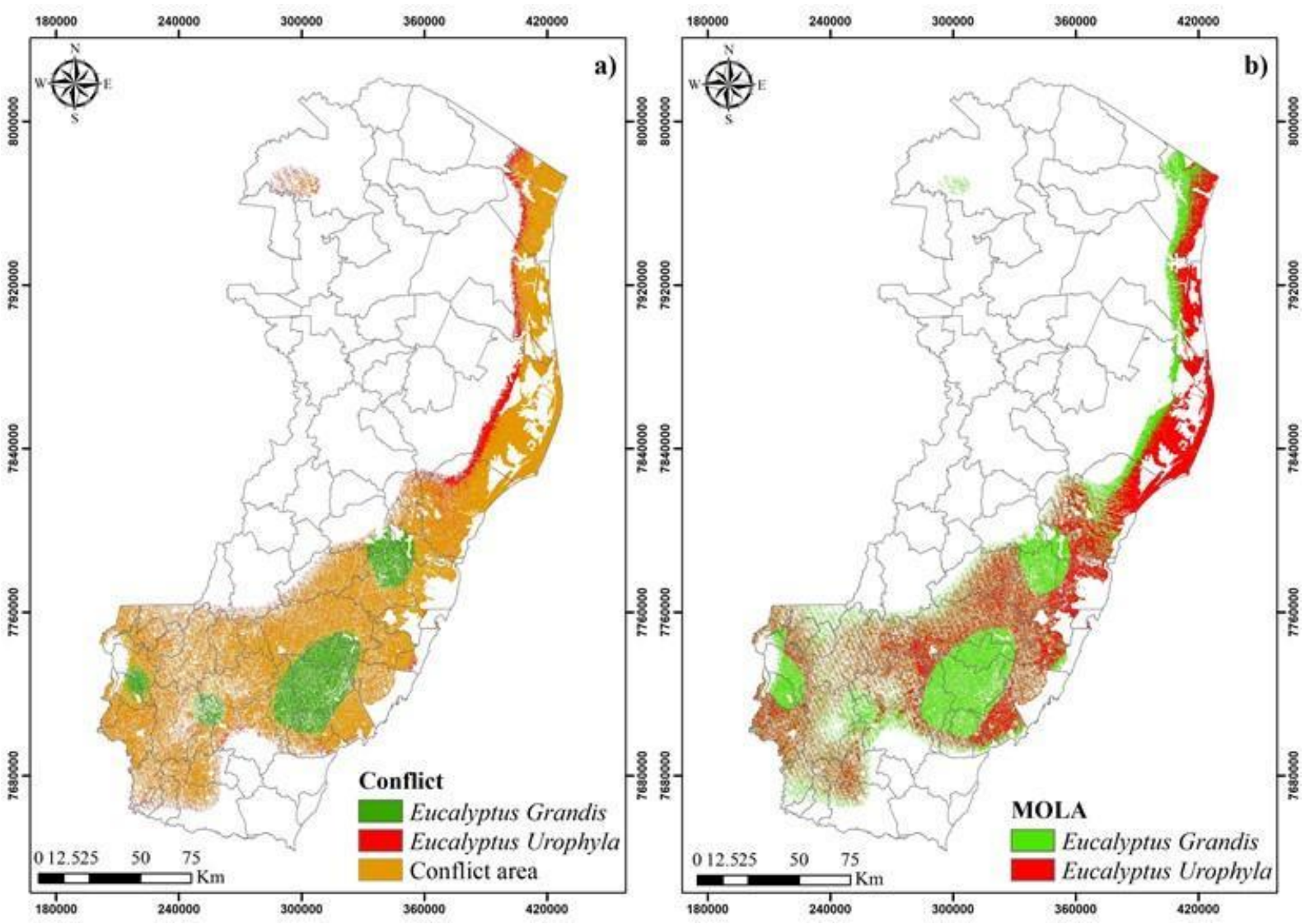

Figure 5. Conflict and aptitude map between different eucalyptus varieties (a) and adequacy map obtained with MOLA tool (b).

Figure 5 shows that the mountainous areas and near the northeast region coast are the most suitable for eucalyptus development, considering the $10,000 \mathrm{~km}^{2}$ of most suitable area for cultivation, and that a large part of this area presents the same climatic conditions for the development of the two species of eucalyptus (Figure 5 (a)). Basically, the difference in fitness between the two species was due to the fact that Eucalyptus grandis tolerate higher precipitation values than Eucalyptus urophylla.

These two varieties were allocated in areas of $5,000 \mathrm{~km}^{2}$ each, having the same weights for each variety. It can be seen (Figure 5 (b)) that most of the conflict areas were allocated for the development of Eucalyptus urophylla. This procedure occurred due to the fact that areas with higher values of total precipitate were used to allocate Eucalyptus grandis.

The climatic zoning presented in this paper indicates the areas with the greatest potential for the planting of eucalyptus in the state of Espírito Santo. However, it is important to emphasize the need for additional studies with other factors (edaphic and specific legislation), as well as the analysis of environmental and socio economic impact of the expansion of eucalyptus forests. According to Targa et al. (2017), the environmental impact analysis is necessary due to the discussion related to the availability of water in watersheds with extensive areas planted with eucalyptus. Arguello et al. (2010) report that socioeconomic impacts include job supply, rural exodus and income generation for small- and medium-sized farms.

\section{IPABH}




\section{CONCLUSIONS}

The state of Espírito Santo was highly climatically suitable to growing both Eucalyptus grandis and Eucalyptus urophyla. The Weighted Linear Combination (WLC) allowed for the identification of suitable areas in the state of Espírito Santo to cultivate both studied varieties. The northwestern region and part of the north region are the ones that showed the smallest adaptability value. The MOLA tool solved the conflict of suitability between the two eucalyptus species. The most suitable areas to plant these two eucalyptus in Espírito Santo are in the mountainous regions, part of the southern and near the northeastern shore, considering the $10,000 \mathrm{~km}^{2}$ most suitable area for eucalyptus cultivation.

\section{REFERENCES}

ALMEIDA, T. S.; CALIJURI, M. L.; PINTO, L. B. Zoneamento agro-climático da cana-deaçucar para o estado de Minas Gerais com base em regressões múltiplas. Revista Brasileira de Meteorologia, v. 28, n. 3, p. 352-355, 2013.

ARGUELLO, F. V. P.; BATISTA, G. T.; PONZONI, F. J.; DIAS, N. W. Distribuição espacial de plantios de eucalipto no trecho paulista da bacia hidrográfica Rio Paraíba do Sul, SP, Brasil. Revista Ambiente \& Água, v. 5, n. 3, p. 133-146, 2010. Hhtp://dx.doi.org/10.4136/ambi-agua.158

BARBIERI, J. D.; DALLACORT, R.; SANTI, A.; ROCHA, R. P.; CARVALHO, M. A. C. Zoneamento agroclimático de amendoinzeiro para a Bacia do Alto Paraguai (MT). Pesquisa Agropecuária Tropical, v. 45, n. 2, p. 231-240, 2015.

BOGNOLA; I. A.; GAVA; J. L.; FASOLO; P. J.; STOLLE, L. Proposição de uma metodologia para identificação de unidades de manejo produtivas em plantios de eucalyptus. Pesquisa Florestal Brasileira, n. 59, p. 27-36, 2009.

CASTRO, F. S.; PEZZOPANE, J. E. M.; CECÍlIO, R. A.; PEZZOPANE, J. R. M.; XAVIER, A. C. Avaliação do desempenho dos diferentes métodos de interpoladores para parâmetros do balanço hídrico climatológico. Revista Brasileira de Engenharia Agrícola e Ambiental, v. 14, n. 8, p. 871-880, 2010.

CALIJURI, M. L.; MELO, A. L. O.; LORENTZ, J. F. Identificação de áreas para implantação de aterros sanitários com o uso de análise estratégica de decisão. Informática Pública, v. 4, n. 2, p. 231-250, 2002.

CARVALHO, J. R. P.; ASSAD, E. D. Análise Espacial da Precipitação Pluviométrica no estado de São Paulo: comparação de métodos de interpolação. Engenharia Agrícola, v. 25, n. 2, p. 377-384, 2005.

FACCO, A. G.; RIBEIRO, A.; PRUSKI, F. F.; MONTEIRO, W. C.; LEITE, F. P.; ANDRADE, R. G. et al. Técnicas de geoinformação para estimativa do balanço hídrico em eucalipto. Pesquisa Agropecuária Brasileira, v. 47, p. 1243-1250, 2012.

FRANCELINO, M. R.; REZENDE, E. M. C.; SILVA, L. D. B. Proposta de metodologia para zoneamento ambiental de plantio de eucalipto. Cerne, v. 18, n. 2, p. 275-283, 2012. http://dx.doi.org/10.1590/S0104-77602012000200012

GOMES, O. M.; SOUZA, F. A. S.; SANTOS, C. A. C.; PAIVA, W. Análise Geoestatística da Precipitação Pluvial do Estado da Paraíba. Revista Brasileira de Geografia Física, v. 4, n. 4, p. 692-702, 2011. 
INDÚSTRIA BRASILEIRA DE ÁRVORES IBÁ. Relatório anual IBÁ 2015. Brasília DF, 2015.

GONÇALVES, M. R.; PASSOS, C. A. M. Crescimento de cinco espécies de eucalipto submetidas a déficit hídrico em dois níveis de fósforo. Ciência Florestal, v. 10, n. 2, p. 145-161, 2000.

KLIPPEL, V. H.; PEZZOPANE, J. E. M.; PEZZOPANE, J. R. M.; CECILIO, R. A.; CASTRO, F. S.; PIMENTA, L. R. Zoneamento climático para Teca, Cedro australiano, Nim indiano e Pupunha no Estado do Espírito Santo. Floresta, v. 43, n. 4, p. 671-680, 2013.

LEITE, E. S.; MINETTE, L. J.; FERNANDES, H. C.; SOUZA, A. P.; AMARAL, E. J.; LACERDA, E. G. Desempenho do harvester na colheita de eucalipto em diferentes espaçamentos e declividades. Revista Árvore, v. 38, n. 1, p. 000-000, 2014. http://dx.doi.org/10.1590/S0100-67622014000100009

MALINOVSKI, R. A.; MALINOVSKI, R. A.; MALINOVSKI, J. R.; YAMAJI, F. M. Análise das variáveis de influência na produtividade das máquinas de colheita de madeira em função das características físicas do terreno, do povoamento e do planejamento operacional florestal. Floresta, v. 36, n. 2, p. 169-182, 2006. http://dx.doi.org/10.5380/rf.v36i2.6459

MENEZES, O. M.; COLLICCHIO, E.; PEREIRA, E. Q.; AZEVEDO, I. R. Edapho-climatic zoning for Eucalyptus urograndis in the state of Tocantins, Brazil. Journal of Bioenergy and Food Science, v. 2, n. 2, p. 62-71, 2015. http://dx.doi.org/10.18067/jbfs.v2i2.36

MIRANDA, E. E. Brasil em Relevo. Campinas: Embrapa Monitoramento por Satélite, 2005.

MORAES, W. B.; JESUS JUNIOR, W. C.; CECILIO, R. A.; MAFIA, R. G.; MORAES, W. B.; COSMI, F. C. et al. Potential impact of the global climate changes on the spatial distribution of areas of risk for the occurrence of eucalyptus rust in Brazil. Summa Phytopathologica, v. 40, n. 2, p. 114-122, 2014. http://dx.doi.org/10.1590/0100$5405 / 1945$

MYBURG, A. A.; GRATTAPAGLIA, D.; TUSKAN, G. A. et al. The genome of Eucalyptus grandis. Nature, v. 510, p. 356-362, 2014. http://dx.doi.org/10.1038/nature13308

PADUA, G. P.; FRANÇA NETO, J. B.; ROSSI, R. F.; CÂNDIDO, H. G. Agroclimatic zoning of the state of Minas Gerais for the production of high quality soybean seeds. Journal of Seed Science, v. 36, n. 4, p. 413-418, 2014. http://dx.doi.org/10.1590/2317$1545 v 36 n 41023$

PEREIRA, A. R.; ANGELOCCI, L. R.; SENTELHAS, P. C. Agrometeorologia: fundamentos e aplicações práticas. Guaíba (RS): Livraria e Editora Agropecuária; 2002.

PEZZOPANE, J. R. M.; CASTRO, F. S.; PEZZOPANE, J. E. M.; BONOMO, R.; SARAIVA, G. S. Zoneamento de risco climático para a cultura do café Conilon no estado do Espírito Santo. Revista Ciência Agronômica, v. 41, n. 3, p. 341-348, 2010.

PINTO, R. C. Verificação de aptidão de áreas selecionadas para instalação de parque de lazer no município de Paranaguá - PR utilizando-se de Sistemas de Informações Geográficas. Geoingá, v. 2, n. 1, p. 83-104, 2010. 
RIBEIRO, A.; PAIVA, Y. G.; BAESSO, R. C. E.; ALMEIDA, A. Q.; OLIVEIRA, A. S.; OLIVEIRA, R. A. et al. Eucalipto. In: MONTEIRO, J. E. B. (Ed.). Agrometeorologia dos cultivos: O fator meteorológico na produção agrícola. Brasília: INMET, 2009.

RIBEIRO, C. A. D.; PEZZOPANE, J. R. M.; PEZZOPANE, J. E. M.; LOOS, R. A.; XAVIER, A. C.; CECÍLIO, R. A. et al. Delimitação de microrregiões agroclimáticas e suas relações com o potencial produtivo da cultura do eucalipto. Floresta, v. 41, n. 4, p. 779-786, 2011. http://dx.doi.org/10.5380/rf.v41i4.25342

RODY, Y. P.; CECÍLIO, R. A.; PEZZOPANE, J. E. M.; RIBEIRO, A.; ALMEIDA, A. Q. Influencia del cambio climático en los escenarios del futuro sobre plantaciones de Eucalipto. Revista Ciência Agronômica, v. 43, n. 3, p. 470-477, 2012.

SANTOS, G. M. A. D. A.; SANTOS, A. R.; TEIXEIRA, L. J. Q.; SARAIVA, S. H.; FREITAS, D. F.; PEREIRA JÚNIOR, O. S. et al. GIS applied to agro climatological zoning and agrotoxin residue monitoring in tomatoes: a case study in Espírito Santo state, Brazil. Journal of Enviromental Management, v. 166, p. 429-439, 2016. https://doi.org/10.1016/j.jenvman.2015.10.040

SARTORI, P. A. Estudo sobre a evolução da área plantada de eucalipto e pinus no Brasil. Revista Científica Eletrônica de Engenharia Florestal, v. 11, p. 139-145, 2008.

SCOLFORO, H. F.; SCOLFORO, J. R. S.; STAPE, J. L.; McTAGUE, J. P.; BURKHART, H.; McCARTER, J. et al. Incorporating rainfall data to better plan eucalyptus clones deployment in eastern Brazil. Forest Ecology and Management, v. 391, p. 145-153, 2017. https://doi.org/10.1016/j.foreco.2017.02.025

SIQUEIRA, J. D. P.; LISBOA, R. S.; FERREIRA, A. M.; SOUZA, M. F. R. de; ARAÚJO, E. de; LISBÃO JÚNIOR, L. et al. Estudo ambiental para os programas de fomento florestal da Aracruz Celulose S.A. e extensão florestal do governo do estado do Espírito Santo. Floresta, v. esp., p. 3-67, 2004.

SOARES, A. Geoestatística para ciências da terra e do ambiente. 2. ed. Lisboa: IST Press, 2006.

SPERANDIO, H. V.; CAMPANHARO, W. A.; CECILIO, R. A.; NAPPO, M. E. Zoneamento Agroecológico para espécies de eucalipto no Estado do Espírito Santo. Caminhos de Geografia, v. 11, n. 34, p. 203-216, 2010.

STOCK, L. A.; FEITOZA, L. R.; CASTRO, L. L. F. Sistema de cálculos climatológicos para o estado do Espírito Santo - CALCLI. Aracê: EMCAPA, 1991.

TARGA, M. S.; BATISTA, G. T.; ALMEIDA, A. A. S.; POHL, E.; PAULA, G. R. Evaluation of soil water storage in native forest and eucalyptus areas. Revista Ambiente \& Água, v. 12, n. 6, p. 973-984, 2017.

TATAGIBA, S. D.; TOLEDO, J. V.; PEZZOPANNE, J. E. M.; ZANETTI, S. S.; CECÍLIO, R. A. Crescimento de mudas clonais de eucalipto em condições de déficit hídrico. Revista Científica Eletrônica de Engenharia Florestal, v. 25, n. 1, p. 16-30, 2015.

TEIXEIRA, C. F. A.; DAMÉ, R. C. F.; BACELAR, L. C. S.; SILVA, G. M.; COUTO, R. S. Intensidade da seca utilizando índices de precipitação. Revista Ambiente \& Água, v. 8, n. 3, p. 203-213, 2013. http://dx.doi.org/10.4136/ambi-agua.1245 
VALVERDE, S. R.; OLIVEIRA, G. G.; SOARES, T. S.; CARVALHO, R. M. A. M. Participação do setor florestal nos indicadores socioeconômicos do estado do Espírito Santo. Revista Árvore, v. 29, n. 1, p. 105-113, 2005. http://dx.doi.org/10.1590/S010067622005000100010

XAVIER, T. M. T.; PEZZOPANE, J. E. M.; PENCHEL, R. M.; CALDEIRA, M. V. W.; REIS, E. F. Influence of water deficit and season on biomass yield from clonal stands of eucalyptus. Cerne, v. 19, n. 3, p. 473-479, 2013. http://dx.doi.org/10.1590/S010477602013000300015 